\title{
Исходный материал и перспективы селекции баклажана на юге России
}

\author{
Initial material of eggplant and prospects of breeding in South of Russia
}

\section{Огнев В.В., Гераськина Н.В.}

\section{Аннотация}

Баклажан имеет широкое распространение на юге России. Площади под культурой имеют тенденцию к росту. Кроме открытого грунта баклажан возделывают в утепленном и защищенном грунте, расширяются и направления использования продукции. Значительные объемы плодов в свежем виде и после промышленной переработки вывозят в более северные регионы. Для каждого направления использования и способа возделывания требуется соответствующий сортимент с комплексом нужных признаков и свойств. Привлечение нового исходного материала позволяет решить основные задачи селекции. Наибольшие перспективы имеет создание исходного материала с высокой продуктивностью в условиях разных способов возделывания, имеющего устойчивость к комплексу неблагоприятных биотических и абиотических факторов среды, лежкого и транспортабельного, пригодного для различных направлений использования и с комплексом морфологических признаков, улучшающих его технологичность в производстве. При выполнении селекционных программ наблюдается недостаток генисточников многих признаков и свойств. Это потребовало проведения специальных исследований по привлечению нового исходного материала. В задачи исследований входили как сбор коллекционного материала, так и его оценка на наличие ценных признаков, создание источников и доноров этих признаков и формирование на их основе банка генплазмы, вовлечение их в селекционный процесс. Исследования проведены в Селекционно-семеноводческом центре «Ростовский» Агрохолдинга «Поиск» в 2010-2019 годах в открытом грунте и весенних теплицах. Почвы в опытах - черноземы обыкновенные. Погодные условия в годы проведения опытов были типичными для климатической зоны юга России. Лето было жарким и сухим, с продолжительными периодами полного отсутствия осадков при температурах свыше $30^{\circ} \mathrm{C}$. Сумма активных температур за вегетационный период превышала $3500{ }^{\circ} \mathrm{C}$, a сумма осадков в среднем составляла 280 мм. Применялись технологии выращивания баклажан, принятые в регионе. Исходный материал изучали по стандартным методикам. На основе проведенных исследований был собран разнообразный материал из разных регионов мира, прежде всего из стран, где культура баклажан наиболее развита (Китай, Индия, Таиланд, Италия, Турция Голландия, Япония и др.). Собранные сорта и гибриды оценивали по наличию ценных признаков и свойств, на их основе создавался линейный материал источников и доноров признаков, востребованных в селекционных программах. Из лучших линий сформирован банк источников и доноров наиболее важных признаков - коллекция генетической плазмы в количестве 70 образцов. Эта коллекция активно вовлечена в селекционные программы по созданию сортимента для юга России и на ее базе получено более 10 сортов и гибридов баклажан, отличающихся по направлениям использования, способам выращивания, с высокой продуктивностью и адаптивными качествами.

Ключевые слова: баклажан, исходный материал, селекция, признаки, направления использования, устойчивость, технологичность, гетерозис.

Для цитирования: Огнев В.В., Гераськина Н.В. Исходный материал и перспективы селекции баклажана на юге России // Картофель и овощи. 2020. №9. С. 35-40. https://doi.org/10.25630/ PAV.2020.22.99.004
Ognev V.V., Geras'kina N.V.

\section{Abstract}

Eggplant is widespread in southern Russia. Areas under the crop tend to grow. In addition to the open ground, the eggplant is cultivated in the comforted and protected soil, and the directions of use of products are expanded. Significant volumes of fruit in fresh form and after industrial processing are exported to more northern regions. Each use and method of cultivation requires an appropriate cultivar with a set of the right features and properties. Attracting new source material allows to solve the main problems of selection. The greatest prospects are the creation of the source material with high productivity in the conditions of different ways of cultivation, which is resistant to a set of adverse biotic and abiotic factors of the environment, lying and transportable, suitable for various uses and with a set of morphological features that improve its technological in production. In the implementation of breeding programs there is a lack of genetic sources of many signs and properties. This required special research to include new source material. The tasks of the research included both collecting the collection material and assessing it for the presence of valuable features, creating sources and donors of these traits and forming a gene plasma bank based on them, involving them in the breeding process. The research was carried out at the Rostovskii Breeding Centre of The Poisk Agro Holding in 2010-2019 in the open ground and spring greenhouses. Soils in experiments are ordinary blackearths. Weather conditions during the years of experiments were typical for the climate zone of southern Russia. Summer was hot and dry, with long periods of complete lack of precipitation in temperatures over $30{ }^{\circ} \mathrm{C}$. The amount of active temperatures during the growing season exceeded $3500{ }^{\circ} \mathrm{C}$, and the amount of precipitation averaged $280 \mathrm{~mm}$. The technologies of eggplants growing adopted in the region were used. Based on the research, a variety of material was collected from different regions of the world, primarily from the countries where the eggplant culture is most developed (China, India, Thailand, Italy, Turkey Holland, Japan, etc.). Collected cultivars and hybrids were evaluated on the presence of valuable features and properties, on their basis created linear material of sources and donors of traits in demand in breeding programs. From the best lines formed a bank of sources and donors of the most important features a collection of genplasma in the number of 70 samples. This collection is actively involved in breeding programs to create a variety for southern Russia and on its basis received more than 10 cultivars and hybrids of eggplant, differing in terms of use, methods of cultivation, with high productivity and adaptive qualities.

Key words: eggplant, source material, selection, signs, directions of use, stability, technology, heterosis.

For citing: Ognev V.V., Geras'kina N.V. Initial material of eggplant and prospects of breeding in South of Russia. Potato and Vegetables. 2020. No1. Pp. 35-40 (In Russ.). https://doi.org/10.25630/PAV.2020.22.99.004 
Б аклажан принадлежит к числу наиболее популярных овощных культур в мире. Наибольшие посевные площади сосредоточены в Китае, Индии и на Ближнем востоке [1]. На юг России баклажан попал с переселенцами с Балкан в очень ограниченном сортименте в начале 18 века. Длительное время здесь доминировал только один сорт - Донской 14 селекции Бирючекутской ОСОС. Сорт наряду с несомненными достоинствами имел и очевидные недостатки: низкую устойчивость к болезням увядания, позднеспелость, шиповатость [2]. На смену ему пришел другой сорт-космополит - Алмаз, более скороспелый, дружно созревающий, многоплодный и малошиповатый [3]. При этом спрос на плоды постоянно рос. Сегодня на одного россиянина производится только 1 кг плодов баклажана, в то время как в Италии, Испании, Японии, Китае, Турции - в 10-12 раз больше [4]. Изменение жизненного уклада, туризм и миграции населения привели к росту спроса в средней полосе и других более северных регионах России, расширились и направления использования, от изготовления различных закусочных консервов до блюд домашней кулинарии и общественного питания, таких как овощи на гриле, шашлыки, мусаки и т.п. Возник спрос на обновление сортимента. А это потребовало привлечения исходного материала с новыми признаками и свойствами. Изучению исходного материала баклажан большое внимание уделяется во многих странах мира. Создаются генетические коллекции, в том числе с использованием методов биотехнологии [5]. Особое внимание как в нашей стране, так и за рубежом уделяется созданию генотипов, устойчивых к болезням увядания $[6,7]$. Учитывая важность баклажан как сырья для консервной промышленности и новых направлений использования, необходимо постоянное совершенствование используемого сортимента, что также требует привлечения новых форм с особыми признаками $[8,9,10]$. Для повышения продуктивности товарных посевов все шире используют селекцию на гетерозис, где необходимы линии с высокой комбинационной способностью $[1,3,7,11]$. Появление и использование в селекции форм баклажана с новыми признаками также требует создания соответствующих банков генплазмы и изучения их особенностей. В качестве примера можно привести геноти- пы со свойством партенокарпии, декоративными качествами и т.п. [8, 12, 13]. Интенсификация процесса селекции баклажан и требования производства делают принципиально важным изучение исходного материала, создание генетических коллекций, выделение образцов с комплексом разнообразных признаков и свойств, реализуемых в новых сортах и гибридах.

В связи с этим, основной целью исследований было изучение исходного материала баклажан различного эколого-географического происхождения и создание на его основе генетической коллекции для селекции сортов и гибридов, пригодных для возделывания на юге России. Для достижения поставленной цели было предусмотрено решение следующих задач:

- подобрать сортообразцы баклажана различного эколого-географического происхождения с комплексом разнообразных морфологических и хозяйственно ценных признаков;

- выявить источники и доноры ценных признаков и свойств для различных направлений селекции;

- создать генетическую коллекцию источников и доноров ценных признаков и свойств;

- вовлечь выделенный исходный материал в селекционный процесс для создания сортов и гибридов баклажан для различных технологий возделывания и направлений использования.

Условия, материалы и методы исследований

В качестве материала для исследований было изучено более 300 copтов и гибридов баклажан, полученных из мировой коллекции ВНИИР имени Н.И. Вавилова, от международных и отечественных селекционносеменоводческих компаний, собранных в результате экспедиций в различные регионы мира (Китай, Индия, Таиланд, Италия, Турция Голландия, Япония и др.). Собранный материал оценивали по комплексу признаков в условиях открытого и защищенного грунта и на провокационных фонах. Использовали стандартные методики оценки [14]. На основе выделившихся образцов получали инцухтлинии, которые представляли собой источники или доноры ценных признаков и свойств. Созданные линии также оценивались по комбинационной способности с выделением лучших для селекции на гетерозис.
Исследования проводили в 20102019 годах на базе Селекционносеменоводческого центра «Ростовский» Агрохолдинга «Поиск», расположенного в Октябрьском районе Ростовской области в открытом грунте и в весенних теплицах с поликарбонатным светопрозрачным покрытием. Почвы в опытах чернозем обыкновенный с высоким содержанием доступных элементов питания. Поливы - через систему капельного орошения с фертигацией. Применяемая технология выращивания баклажана - принятая для зоны [10]. Территория хозяйства расположена в степной зоне с жарким и сухим летом и неустойчивой, относительно теплой зимой. К числу неблагоприятных факторов внешней среды относятся высокие температуры и недостаток увлажнения в период вегетации, а также наличие в почве возбудителей болезней увядания. За вегетационный период сумма активных температур свыше $10{ }^{\circ} \mathrm{C}$ превышает $3500{ }^{\circ} \mathrm{C}$, сумма осадков достигает 280 мм. Погодные условия в период проведения опытов характеризовались как типичные для региона с летними температурами выше $+30{ }^{\circ} \mathrm{C}$ и недостатком осадков. Периоды засух продолжались в течение 15-20 дней, когда относительная влажность воздуха снижалась до 19-20\%.

\section{Результаты исследований}

За годы проведения исследований была изучена коллекция из более чем 300 сортообразцов, полученных из ВНИИР имени Н.И. Вавилова, от отечественных и иностранных селекционно-семеноводческих компаний, и в результате экспедиционного сбора материала в странах широкого распространения культуры баклажан (Китай, Индия, Таиланд, Италия, Турция Голландия, Япония и др.). Полученные сортообразцы оценивали в открытом и защищенном грунте и на провокационных фонах по комплексу признаков, как морфологических, так и хозяйственных. Вели поиск геноносителей высокой продуктивности, крупноплодности, многоплодности, устойчивости к болезням увядания и абиотическим факторам среды, высокой завязываемости, морфологических признаков растений и плодов, их технологических признаков, представляющих интерес для различных направлений селекции.

Большая часть привлеченного материала была представлена гибридами первого поколения. Оценка 
полученного исходного материала показала, что в среднем за все годы изучения гибриды $\mathrm{F}_{1}$ баклажана достоверно превышали свободноопыляющиеся сорта на 35-124\% по величине общей урожайности. Общемировой тенденцией является создание именно гетерозисных гибридов первого поколения. Все иностранные компании в коммерческом сортименте имеют только гибриды $\mathrm{F}_{1}$.

По продуктивности выделяются сортообразцы из Китая, Индии и Голландии. Анализ структуры урожая показал, что наиболее урожайные генотипы имеют более высокую массу отдельного плода и формируют большее количество плодов на растении. Большая часть представленных в коллекции гибридов создана за последние 25-30 лет. Среди самых урожайных гибридов баклажан сравнительно немного скороспелых форм, представляющих интерес для России. В качестве источников высокой продуктивности, товарности урожая, многоплодности, скороспелости и других признаков целесообразно использовать гибриды $\mathrm{F}_{1}$ Valentina и $\mathrm{F}_{1}$ Samurai из Голландии. На основе этих гибридов получен линейный материал, являющийся донором крупноплодности, многоплодности и скороспелости.

Этот материал активно использован в селекции на гетерозис. Выделенные линии показали высокую комбинационную способность,
Таблица 1.Оценка поражения сортообразцов баклажана фузариозом в открытом грунте на жестком инфекционном фоне (среднее за 2014-2018 годы)

\begin{tabular}{|l|c|c|}
\hline \multicolumn{1}{|c|}{ Образец } & $\begin{array}{c}\text { Средний балл } \\
\text { поражения }\end{array}$ & $\begin{array}{c}\text { Степень развития } \\
\text { болезни, \% }\end{array}$ \\
\hline Алмаз, устойчивый стандарт & 1,5 & 37,5 \\
\hline Донской 14, восприимчивый стандарт & 3,8 & 94,8 \\
\hline Халиф & 0,6 & 15,2 \\
\hline Меч самурая & 0,8 & 20,0 \\
\hline Галич & 1,0 & 24,6 \\
\hline Нистру & 1,0 & 24,9 \\
\hline F, ЕG 203 & 1,2 & 30,0 \\
\hline F, Максик & 1,2 & 30,4 \\
\hline F, Валентина & 1,6 & 40,4 \\
\hline
\end{tabular}

а гибридные комбинации на их основе превышали по продуктивности лучшие родительские линии на $21,8-52,1 \%$

В то же время, самыми многоплодными были полукультурные местные формы с кистевым плодоношением из Индии и стран ЮгоВосточной Азии. Самую большую массу отдельного плода имели образцы из Китая, США и Индии. У отдельных сортообразцов она превышала 1,2-2,0 кг. Доноры многоплодности и кистевого плодоношения образцы из Индии $F_{1}$ Haksha и $F_{1}$ Green emerald, а также образец из СШA Gretel. Источники крупноплодности - сорта из США и Китая: Кит 173/16 F, Кит 277/13 и Ам 12/10.

В условиях жары и засухи у баклажана наблюдается нарушение процессов опыления и формирования плодов, значительная часть цветков и плодов осыпается. Из числа изученных сортообразцов только незначительная часть отличается высокой завязываемостью в неблагоприятных условиях. Частично решить проблему помогает способность отдельных образцов формировать партенокарпические плоды. Наиболее выражено свойство партенокарпии в условиях весенних теплиц. Здесь выделились по способности формировать партенокарпические плоды образцы из России Десерт Голиафа и $\mathrm{F}_{1}$ Максик

Большую проблему при выращивании баклажан представляют болезни увядания грибной природы, распространенные в регионе. Генотипы, отличающиеся высокой устойчивостью, в изученном сортименте отсутствуют. Относительную устойчивость

Таблица 2. Характеристика линий и гибридов баклажана в условиях открытого грунта (среднее за 2016-2018 годы)

\begin{tabular}{|c|c|c|c|c|}
\hline Образец & Группа спелости & Урожайность, кг/м² & Средняя масса плода, г & $\begin{array}{c}\text { Средний балл поражения } \\
\text { увяданием }\end{array}$ \\
\hline Алмаз, устойчивый стандарт & среднеранний & 2,9 & 180,0 & 1,5 \\
\hline $\begin{array}{l}\text { Донской } 14, \text { восприимчивый } \\
\text { стандарт }\end{array}$ & среднеспелый & 3,2 & 280,4 & 3,8 \\
\hline Линия 47 & ранний & 3,7 & 250,0 & 0,6 \\
\hline Линия 68 & ранний & 4,2 & 250,8 & 0,8 \\
\hline Линия Кит 132/12 & среднеспелый & 3,8 & 290,2 & 1,2 \\
\hline Линия Кит 277/13 & среднеспелый & 3,6 & 280,6 & 1,2 \\
\hline Линия Кит 173/16 & среднеспелый & 3,4 & 250,4 & 1,2 \\
\hline Линия Кит 187/16 & среднеспелый & 3,4 & 240,8 & 1,2 \\
\hline Линия Алм 12/10 & среднеранний & 3,4 & 180,8 & 1,2 \\
\hline Линия Макс & ранний & 2,4 & 140,6 & 1,2 \\
\hline Линия Вал & ранний & 2,8 & 160,9 & 1,6 \\
\hline Гибрид 1/16 (Л 47×Л Алм) & ранний & 5,1 & 240,3 & 1,0 \\
\hline Гибрид 2/16 (Л 47×Л Вал) & ранний & 4,8 & 220,4 & 1,0 \\
\hline Гибрид 2/17 (Л68×Л Алм) & ранний & 4,6 & 230,4 & 1,0 \\
\hline Гибрид 4/18 (Л68×Л Вал) & ранний & 4,8 & 240,8 & 1,2 \\
\hline Гибрид 6/18 (Л Макс×Л Вал) & ранний & 4,0 & 220,3 & 1,2 \\
\hline $\mathrm{HCP}_{05}$ & & 0,14 & 12,2 & \\
\hline
\end{tabular}




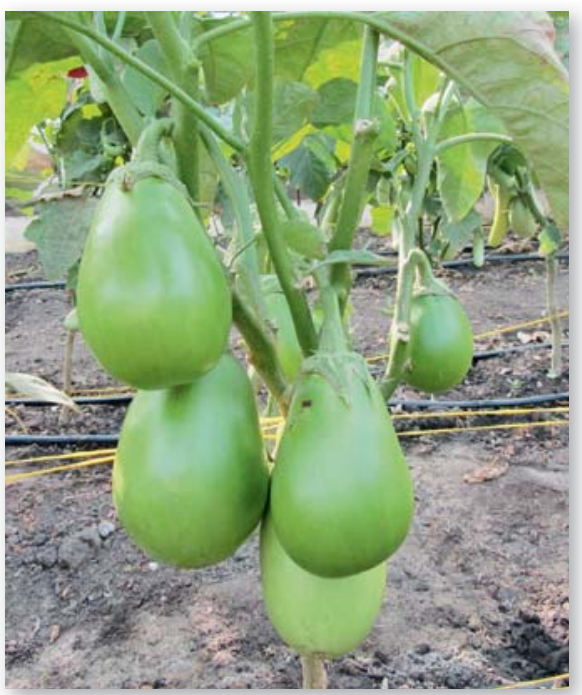

Кит 132.12

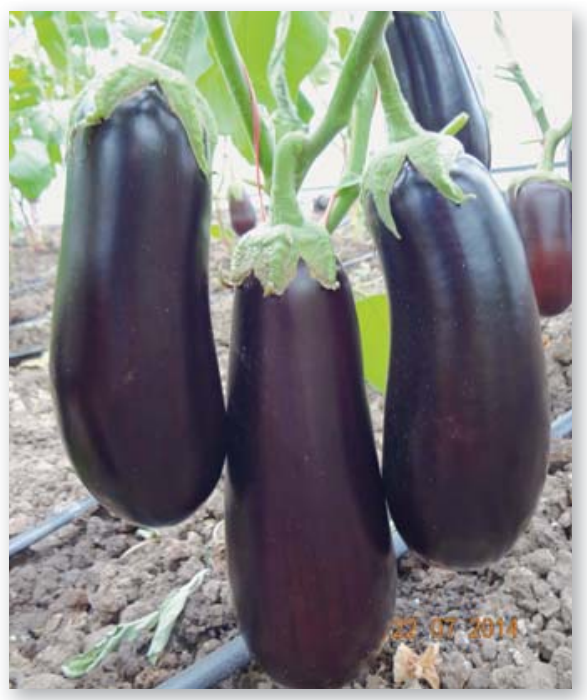
$F_{1}$ Максик

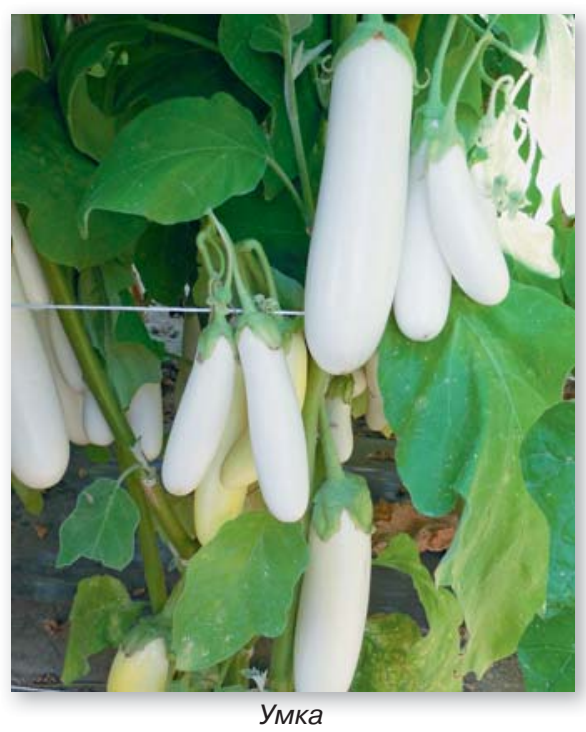

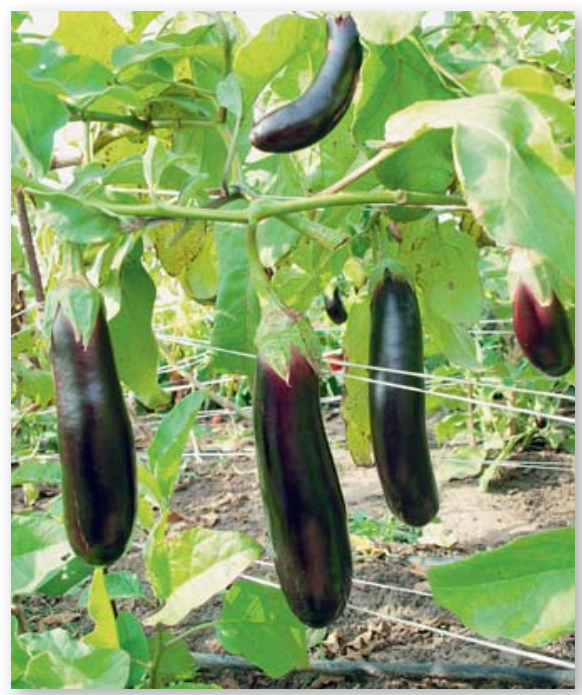

Халиф

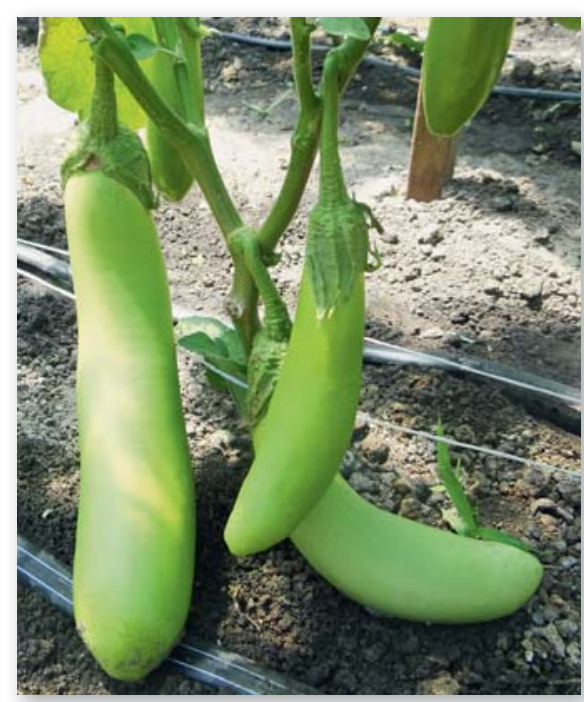

Кит 187.16
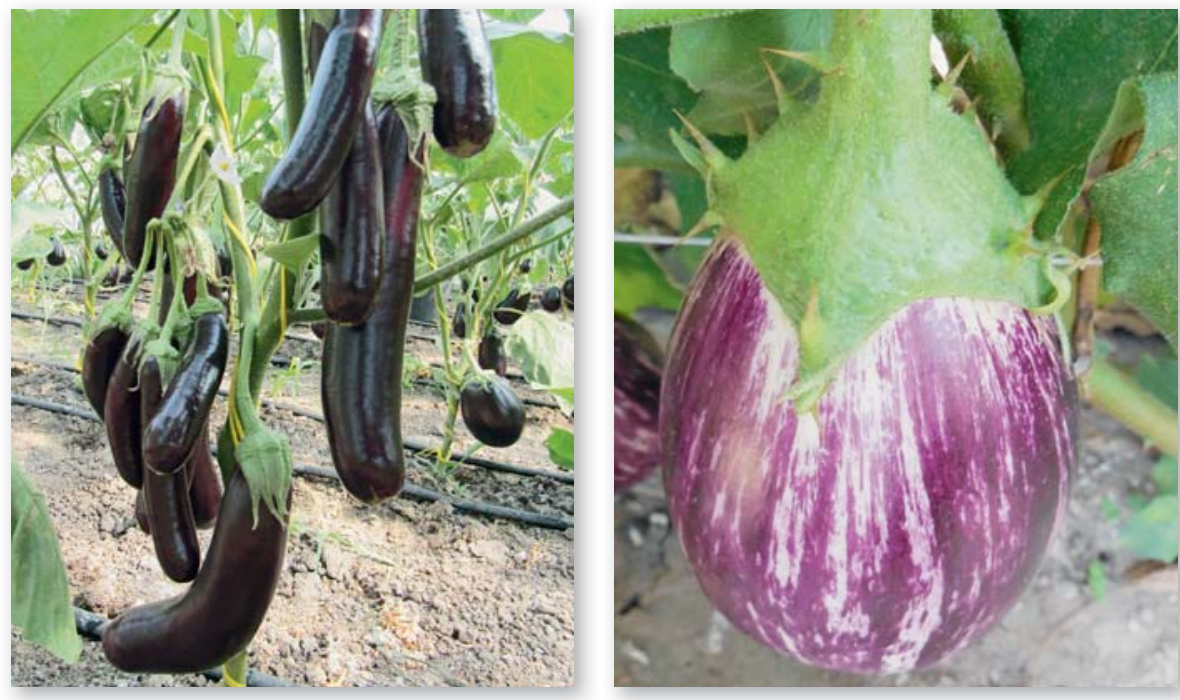

Образец с сильной шиповатостью

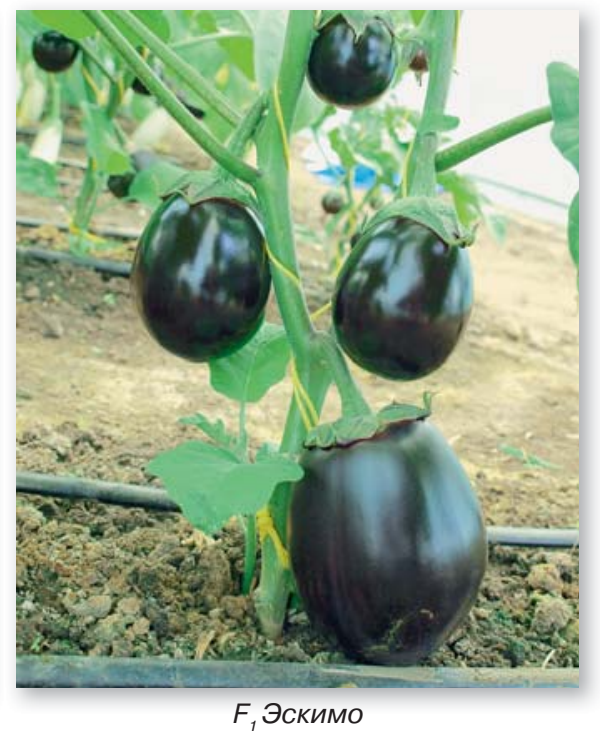


показали сорта местной селекции Алмаз, Галич, Халиф, Меч самурая, $F_{1}$ Максик и гибрид из Китая F EG 203. Полученный на основе этих образцов линейный материал в условиях жесткого инфекционного фона также показал относительно высокую устойчивость к болезням увядания. Этот материал также включен в селекционные программ (табл. 1, 2).

Расширение масштабов выращивания баклажан в весенних теплицах потребовало создания специальных сортов с небольшим габитусом растений, более слабой ветвистостью и облиственностью, полностью бесшипных и с высокой завязываемостью плодов. Компактный габитус позволяет создавать сорта с продолжительным периодом плодоношения, которые эффективно используют пространство теплицы при этом не самозагущаясь. Компактный габитус имело большое количество сортов из Южной Азии, но они все были мелкоплодными и больше подходили для контейнерной культуры. Из высокопродуктивных сортов с небольшим габитусом выделились сорта отечественной селекции Алмаз,
Галич, Кировский и украинский сорт Надир, а также гибриды $F_{1}$ Максик и $F_{1}$ Валентина. Бесшипность очень важна для облегчения проведения операций по сбору урожая, формировке и подвязке растений. Доноры признака бесшипности - образцы из Голландии, Италии и Франции. Среди старых отечественных сортов по этому признаку выделяется сорт Алмаз, являющийся сложной популяцией по степени шиповатости. Линейный материал с признаком бесшипности получен из сорта Алмаз и гибрида $\mathrm{F}_{1}$ Valentina. Высокую завязываемость плодов в условиях теплиц показали гибриды из Италии и Франции, а также отечественный гибрид $\mathrm{F}_{1}$ Максик. Свойство партенокарпии проявили сорта Халиф, Меч самурая, Десерт Голиафа и гибрид $\mathrm{F}_{1}$ Максик.

Плоды баклажан широко используют не только в домашней кулинарии, но и в качестве сырья для консервной промышленности, а также в общественном питании. К сортам для каждого направления использования предъявляют специфические требования. Прежде всего эти требования касаются морфологии и анатомии плодов. Если раньше выращивали только образцы с темнофиолетовой, почти черной окраской плодов, то в последнее время все большей популярностью пользуются плоды с альтернативной окраской - зеленой, белой, пестрой. Зеленоплодные формы широко представлены в Китае. Крупные цилиндрические плоды имеет образец Кит 187/16, а плоды грушевидной формы Кит 132/12. Это наиболее урожайные образцы, имеющие комплекс хозяйственно ценных признаков. Белоплодные сортообразцы получены как из Китая, так и из Турции, есть они и среди сортов отечественной селекции. Округлые белые плоды имеют сорта отечественной селекции Снежный шар и Альбион, а цилиндрические - сорта Пеликан, Сосулька, Умка. Среди форм с пестрыми плодами выделяются сорт отечественной селекции Матросик и гибрид из Японии EP 11073 F. Образцы с лиловой окраской характерны для Китая. Они имеют более рыхлую мякоть, многоплодность и высокую продуктивность. Наиболее урожайным из изученных был образец Кит $177 / 16$. Более плотную мякоть имели плоды сортов и гибридов отечественной селекции Донской 14, Батайский, Универсал 6, Алмаз, Галич. Среди иностранных выделился образец Green shoulder из Китая. Разнообразие образцов по форме, размерам и окраске плодов, их плотности, содержанию сахаров и другим признакам позволяет создавать исходный материал с требуемыми параметрами для различных направлений использования.

\section{Выводы}

Были изучены более 300 сортообразцов баклажан различного эколого-географического происхождения в условиях открытого и защищенного грунта и на провокационных фонах.

Среди изученных сортообразцов баклажан были выявлены геноносители ценных признаков для различных направлений селекции культуры в условиях юга России.

Из лучших образцов создан банк источников и до- 
норов наиболее важных признаков коллекция генплазмы в количестве 75 линий. Линейный материал включал источники и доноры с высокой продуктивностью и комбинационной способностью (10), устойчивостью к болезням увядания и абиотическим факторам среды (20), с разнообразным габитусом растений, различной окраской, формой и другими характеристиками плодов (45).

Источники и доноры ценных признаков активно вовлечены в селекционные программы по созданию сор- тимента для юга России. Всего получено более 10 сортов и гибридов, отличающихся по направлениям использования, способам выращивания, с высокой продуктивностью и адаптивными качествами.

\section{Библиографический список}

1.Баклажан (Solanum ssp.) /М.И. Мамедов, О.Н. Пышная, Е.А. Джос и др. М.: ВНИИССОК. 2015. 264 с.

2.Лудилов В.А., Фомин В.А. Томаты, перцы, баклажаны: рекомендации (Библиотечка овощевода). Ростов-на-Дону: Ростиздат. $1981.56 \mathrm{c}$.

3.Гераськина Н.В. Гетерозисная селекция баклажана // Картофель и овощи. 2015. №12. С. 35.

4.Магомедов Р.К. Хранение плодов баклажана: как сократить потери //Картофель и овощи. 2014. №4. С. 20-21.

5.Cericola F., Portis E., Toppino L. et al. Morphological and molecular diversity of an eggplant (S. melongena L.) germplasm collection. 15 EUCARPIA meeting on genetics and breeding of Capsicum and Eggplant. 2013. Torino. Italy. P.575-580.

6.Boyaci F., Gumrukçu E., Topçu V., Unlu A., Oten M. Improvement of resistant eggplant lines against Fusarium ( $F$. oxysporum Schlecht. f. sp. melongenae). 15 EUCARPIA meeting on genetics and breeding of Capsicum and Eggplant .2013. Torino. Italy. P.289-294.

7.Гераськина Н.В. Селекция баклажана для юга России // Картофель и овощи. 2016. №7. С. 33-34.

8.Кигашпаева О.П., Авдеев А.Ю. Новые сорта баклажана для консервирования // Картофель и овощи. 2016. №7. С. 35-36.

9.Гераськина Н.В. Усовершенствованная шкала шиповатости баклажана // Картофель и овощи. 2014. №4. С. 30-31.

10.Гераськина Н.В., Огнев В.В. Особенности выращивания белоплодных форм баклажана // Картофель и овощи. 2018. №7. C. $12-15$.

11.Prasad V., Dwivedi V.K., Deshpande A.A., Singh B.K. Heterosis for yield and other yield contributing economic traits in eggplant (S. melongenae). 15 EUCARPIA meeting on genetics and breeding of Capsicum and Eggplant. 2013. Torino. Italy. Pp. 697-700.

12.Trotta N., Pepe R., Rofrano G., Piro F. Morpho-phenological traits of parthenocarpic germplasm of Solanum melongena $\mathrm{L}$. bred at the CRA Vegetable Research Center. 15 EUCARPIA meeting on genetics and breeding of Capsicum and Eggplant. 2013. Torino. Italy. Pp. 655-660.

13.Toppino L., Giovino A., Diliberto G. at al. Introgression breeding in eggplant for agronomical and ornamental purposes. 15 EUCARPIA meeting on genetics and breeding of Capsicum and Eggplant. 2013. Torino. Italy. Pp. 723-727.

14.Литвинов С.С. Методика полевого опыта в овощеводстве. М.: ВНИИО, 2011.648 с.

\section{References}

1.Mamedov M.I., Pishnaya O.N., Dzhos E.A. et al. Eggplant (Solanum ssp.). Moscow. VNIISSOK. 2015. 264 p. (In Russ.).

2.Ludilov V.A., Fomin V.A. Tomatoes, peppers, eggplants. Rostovon-Don. 1981.56 p. (In Russ.).

3.Geras'kina N.V. Eggplant breeding for heterosis. Potato and vegetables. 2015. No12. P. 35 (In Russ.).

4.Magomedov R.K. Storage of eggplants: how to reduce losses. Potato and vegetables. 2014. No4. Pp. 20-21 (In Russ.).

5.Cericola F., Portis E., Toppino L. et al. Morphological and molecular diversity of an eggplant (S. melongena L.) germplasm collection. 15 EUCARPIA meeting on genetics and breeding of Capsicum and Eggplant. 2013. Torino. Italy. Pp. 575-580.

6.Boyaci F., Gumrukçu E., Topçu V., Unlu A., Oten M. Improvement of resistant eggplant lines against Fusarium ( $F$. oxysporum Schlecht.f. sp. melongenae). 15 EUCARPIA meeting on genetics and breeding of Capsicum and Eggplant .2013. Torino. Italy. Pp. 289-294.

7.Geras'kina N.V. Prospective breeding of eggplant in southern Russia. Potato and vegetables. 2016. No7. Pp. 33-34 (In Russ.).

8.Kigashpaeva O.P., Avdeev A.Yu. New cultivars of eggplant for canning. Potato and vegetables. 2016. No7. Pp. 35-36 (In Russ.).

9.Geras'kina N.V. Improved scale of assessment of eggplant thorns. Potato and vegetables. 2014. No4. Pp. 30-31 (In Russ.).

10.Geraskina N.V., Ognev V.V. Characteristics of growing whitefruit forms of eggplant. Potato and vegetables. 2018. No7. Pp. $12-$ 15 (In Russ.).

11.Prasad V., Dwivedi V.K., Deshpande A.A., Singh B.K. Heterosis for yield and other yield contributing economic traits in eggplant (S. melongenae). 15 EUCARPIA meeting on genetics and breeding of Capsicum and Eggplant. 2013. Torino. Italy. Pp. 697-700.

12.Trotta N., Pepe R., Rofrano G., Piro F. Morpho-phenological traits of parthenocarpic germplasm of Solanum melongena $L$. bred the CRA Vegetable Research Center. 15 EUCARPIA meeting on genetics and breeding of Capsicum and Eggplant. 2013. Torino. Italy. Pp. 655660 (In Russ.).

13.Toppino L., Giovino A., Diliberto G. at al. Introgression breeding in eggplant for agronomical and ornamental purposes. 15 EUCARPIA meeting on genetics and breeding of Capsicum and Eggplant. 2013. Torino. Italy. Pp. 723-727.

14.Litvinov S.S. Methodology of field experiment in vegetable production. Moscow. VNIIO. 2011. 648 p. (In Russ.).

\section{Об авторах}

\section{Author details}

Огнев Валерий Владимирович, канд. с.-х. наук, доцент, директор ССЦ «Ростовский» Агрохолдинга «Поиск». E-mail: ognevvv@bk.ru

Гераськина Надежда Викторовна, канд. с.-х. наук, селекционер ССЦ «Ростовский» Агрохолдинга «Поиск». E-mail: geraskina.89@mail.ru

Ognev V.V., Cand. Sci. (Agr.), associate professor, director of Rostovsky breeding centre of Poisk Agro Holding. E-mail: ognevvv@bk.ru

Geras'kina N.V., Cand. Sci. (Agr.), breeder of Rostovsky breeding centre of Poisk Agro Holding. E-mail: geraskina.89@mail.ru

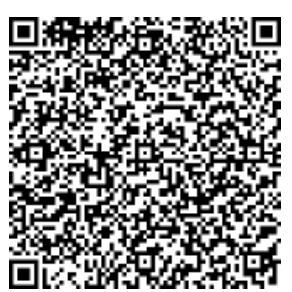

АДРЕС ДЛЯ ПЕРЕПИСКИ:

140153 Московская область, Раменский район, д.Верея. стр.500, В. И. Леунову ail: kio@potatoveg.ru тел. 7 ( 49646$) 24-306$ Российской Федерации по

массовых коммуникаций.
Свидетельство № 016257 ๑ Картофель и овощи, 2020

ВАК РФ для публикации трудов аспирантов и сой Информация об опубликованных статьях поступает в систему Российского индекса научного цитирования (РИнц)

Журнал входит в перечень издв Научным статьям присваивается цифровой идентификатор объекта DOI (Digital Object Identifier).

Подписано к печати 15.01.20. Формат 84х1081/16 Бумага глянцевая меловананая. Печать офсетная. Усл. печ. . . 4,2 Заказ № 64 Отпечатано в ГУП РО «Рязанская областная типография» 390023, г.Рязань, ул. Новая, д 69/12. 